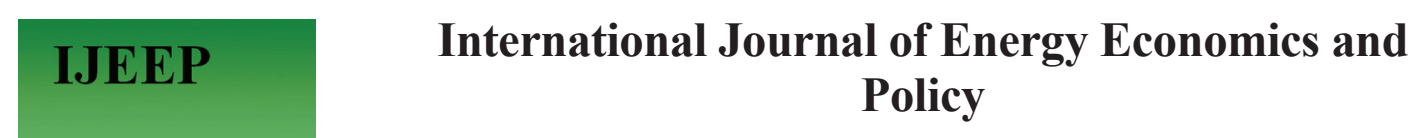

ISSN: $2146-4553$

available at http: www.econjournals.com

International Journal of Energy Economics and Policy, 2022, 12(1), 54-61.

\title{
Sustainable Electricity Supply and Poverty Reduction in Nigeria
}

\section{Oluwasegun Eseyin*, Joseph Olufemi Ogunjobi}

Department of Economics, Landmark University, Omu-Aran, Nigeria. *E-mail: oluwaseguneseyin@gmail.com; eseyin.oluwasegun@1mu.edu.ng

Received: 12 October 2020

Accepted: 19 October 2021

DOI: https://doi.org/10.32479/ijeep.10746

\begin{abstract}
The poverty situation in the rural areas of the country deserves greater attention; the available statistics from the NBS reveal that the majority of the poor are located in the rural areas. It is really impossible to envision industrialization and societal well-being or high standard of living without adequate and reliable electricity supply. Sustainable electricity supply will aid the artisans, traders, farmers with storage facilities, reduce the rural-urban immigration, improve the standard of living in the rural areas, and encourage rural industrialization and capital formation. This study investigates the impact of sustainable electricity supply on poverty reduction in Nigeria. A time series data from 1981 to 2018 was analysed for this study. Based on the outcome of this study, it could be seen clearly that while electricity generation play a significantly role reducing poverty in the country, electricity consumption does not guarantee poverty reduction. Also, apart from the fact that poverty level in the past period is found to have a direct and statistically significant effect on the poverty rate in the current period, it was also revealed that lower unemployment rate does not really translate into reduction in the poverty level in Nigeria. The study therefore recommend that electricity generation should be given more attention and while trying to address the menace of unemployment in the country, underemployment and labour exploitation must also be tackled headlong.
\end{abstract}

Keywords: Electricity Supply, Power, Energy, Poverty Reduction and Economic Growth

JEL Classifications: Q4, I32, O55, O13, F63

\section{INTRODUCTION}

The demand for electricity has been growing rapidly with the growth of economy, changes in demographic structure, rising in Urbanization and Socio-economic growth. The demand for electricity has been growing rapidly with the growth of economy, changes in demographic structure, rising in urbanization and Socio-economic development (Kumar, 2009). Despite some achievements in economic growth over the years, poverty has persisted; rural poverty and conditions of living have worsened. What is cleared is that economic growth in Nigeria has neither been broad-based nor inclusive growth and it has not automatically translated into improvement in living conditions for the majority of the Nigerian. The pattern of growth has also resulted in unequal access of people to resources and wealth in general.

Electricity serves as a carrier of energy to the user. Energy present in a fossil fuel nuclear fuel and renewable (hydro, geothermal, tidal, wind, solar, biomass etc.) is converted to energy in the form of electricity in order to transport and readily distribute it to customers. By means of transmission and distribution lines, electric power is transmitted and distributed to the end-users in all the sectors of a natural economy. Electricity is one of the live wires to effective industrialization of a nation.It is a very high quality energy form and its versatility, flexibility, adaptability and amenability to control are unmatched. In addition, the cleanliness, convenience, familiarity and rehabilitee of electricity make it the choice of energy in many applications.

In Nigeria, a study by Adegbulugbe and Akinbami (2002) concluded that "electricity is the preferred energy source for household activities in the urban areas because of its convenience and low operating costs and associated benefits to its users." Hence, there must be adequate and stable electricity supply for a progressive and positive growth of an economy. Onabote, Abuh

This Journal is licensed under a Creative Commons Attribution 4.0 International License 
, Oduntun, Eseyin and Okafor (2020) posit that availability and stability of power supply are critical to the performance of the manufacturing sector and aggregate output. Energy does not only spur to creation, but it also enhances the global competitiveness of the country's product, a rise in the overall national output. In the same vein, Ogunjobi, Eseyin and Popoola (2020) discovered that energy shortage could slow down the pace of economic growth in most developing nations. According to their study, the shortfall in Nigeria's electricity supply has grown from bad to worse. Awhile recognizing the germane role of this sector to general economic fortune of the country, every aspiring politician that intends to navigate their ways into the seat of power usually put it as their primary agenda to fix. This is a dream that is still struggling to find fulfillment in the country till now. Hence, more Nigerians continue to find themselves living below the poverty line.

In the 21 st century, electricity continues to demonstrate its societal value and versatility as a major energy source.Sustainable electricity supply embraces a number of practices, policies and technologies that seek to provide us with the energy needed at the least financial, environmental and social costs. Such supply strategies should be done on the basis of cost-effectiveness, continuous availability, unrestricted supply and satisfactory regard for the environment. Provision of adequate power (electricity) to drive economic activity has been a major reason for the occurrence of the East Asian miracle, when countries in the region attained and sustained double-digit gross domestic product (GDP) growth rates for several years in the 21 st century. Considering the importance of the sector to economic development, it is therefore no surprise that the decline in the power sector over the years has been a key reason for the rather dismal performance of the rural Nigerian economy.

The poverty situation in the rural areas of the country deserves greater attention; the available statistics from the NBS reveal that the majority of the poor are located in the rural areas. The rural areas were worse off than the urban. They have been largely underserved in terms of access to social and economic infrastructure and service.Another reason for this study is the failure of the trickledown effect theory of growth in Nigeria. Despite some achievements in economic growth over the years, poverty has persisted and rural poverty and conditions have worsened. The economic growth in Nigeria has neither been broadbased nor inclusive. This has not translated into improvement in living conditions for the majority of Nigerian people. The pattern of growth has also resulted in unequal access of people to resources and wealth in general. According to Ulsrud et al. (2015) and Groh (2014) emphasized the importance of access to energy as a stimulator of economic development, broadening the scope of education, reducing poverty and improving the health care delivery and health care status of the citizenry.The International Energy Agency (2017) as cited by Kayode, Benjamin, Seiichi and Tetsuo (2018) confirmed that over one billion people around the world remained without access to electricity in 2014, majority of this were in Ethiopia, Indian, DR Congo, Bangladesh and Nigeria.

World Bank (2017) categorized Nigeria as a middle income country with about $\$ 2790$ per capital income. The poor or under developed energy sector has serious implications in its economic growth and development. Firstly, rural-urban drift has really affected its agricultural growth and productivity. Absence of electricity in the rural areas either for agricultural products storage, agro-allied industries development and especially for the welfare status of the young farmers has made them abandoned their farms to the cities where they can enjoy these infrastructures. Secondly, it has affected her industrialization drives as most productive multinational companies in textiles, breweries, cosmetics; drugs have relocated to other countries where they enjoy sustainable electricity supply thereby increasing the unemployment rate and the poverty rates respectively. Thirdly, the cost implications of using alternative electricity supply through diesel/generators on the cost of production and prices of their products thereby making the imported goods cheaper to their local ones, this have encouraged imported goods to the detriment of the locally produced goods and the GDP.

Simpson (1969), Breshin (2004) and Sanchis (2007) describe electricity as vital for economic growth in manufacturing, telecommunication and not only on the factor of production, but also on its impact on capital formation. According to Alamu and Abiodun (2006), there is a departure from new-classical economies which include only capital, labour and technology as factors of production to conclusion that energy drives the work that converts raw materials into finished products in the manufacturing process. The consumption of electricity in Nigeria and other African Countries is extremely low compare with the developed countries. Table 1 reveals the comparison between some developed and developing countries between 2014 and 2015 in terms of electricity consumption.

There is a strong body of evidence that there is an extremely strong nexus between a robust power sector and increased levels of economic growth Makoju (2002). The power sector directly or indirectly affects the efficacy and competitiveness of every critical economic and social activities. Such include education, agriculture, health, manufacture, banking and finance, commerce and entrepreneurship. These in turn attract foreign direct investment (FDls) and provision of portable water etc.

The description of Nigeria as paradox by the World Bank (1996) has continued to be confirmed by the events and official statistics in the country. The paradox is that the poverty level in Nigeria contradicts the country's immense wealth. Among other things, the country is greatly endowed with human, agriculture, petroleum, gas and both tapped and untapped solid mineral resources. But rather than record remarkable progress in natural socio-economic development. Nigeria retrogressed to become one of the 25 poorest countries at the threshold of the twenty-first century whereas she was among the richest in the early 1970s.

Apparently, the poverty situation in the country deserves greater focus for a member of reasons. Firstly, available statistics from the federal office of statistics reveal that majority of the poor are located in the rural areas. The proportion of the rural population in poverty increased from $28 \%$ in 1980 to $51 \%$ in $1985,72 \%$ in 1996 and $78 \%$ in 2005 but reduced to $72 \%$ in 2010 . Also the rural areas were also worse off than the urban. The rural areas have been largely underserved in terms of access to economic infrastructure and services. The rural 
Table 1: List of some countries and electricity consumption

\begin{tabular}{|c|c|c|c|c|c|}
\hline Country & $\begin{array}{l}\text { Electricity consumption } \\
\text { (kwh/year) in millions) }\end{array}$ & $\begin{array}{l}\text { Year of date's } \\
\text { estimate }\end{array}$ & $\begin{array}{l}\text { Population as at } \\
2016 \text { in millions }\end{array}$ & $\begin{array}{c}\text { Average Electrical Energy } \\
\text { PerCapital } \\
\text { (KWH per person per year) }\end{array}$ & $\begin{array}{c}\text { Average Power per } \\
\text { Capital (watts per } \\
\text { person) }\end{array}$ \\
\hline USA & $3,911,000$ & 2015 & 324 & 12,071 & 1377 \\
\hline Canada & 528,000 & 2014 & 35.4 & 14,930 & 1704 \\
\hline South Korea & 495,000 & 2014 & 50.9 & 9720 & 1109 \\
\hline Mexico & 238,000 & 2014 & 123.1 & 1932 & 220 \\
\hline France & 431,000 & 2014 & 66.8 & 6448 & 736 \\
\hline South Africa & 212,000 & 2014 & 54.3 & 3904 & 445 \\
\hline Egypt & 143,000 & 2014 & 94.6 & 1510 & 172 \\
\hline Algona & 49,000 & 2014 & 40.2 & 1216 & 138 \\
\hline Morocco & 29,000 & 2014 & 33.6 & 861 & 98 \\
\hline Nigeria & 24,000 & 2014 & 186.1 & 128 & 14 \\
\hline
\end{tabular}

Source: CIA World Facebook website 2017.

areas remain the domain of poverty in Nigeria. Moreover,the fact remains that over 85 million rural majority need to be moved above the moderate poverty line is an issue of consideration and concern. Another reason to focus on rural poverty reduction derives from the picture from available data shows that the core poor are in agriculture and petty trading and all basically reside in the rural areas.

Some scholars, which include Boardman and Kumani (2014), Abdur and Khorsed (2010) have come out that an increased energy consumption is a panacea to poverty reduction as well as a tool for sustaining and enhancing economic growth. Some scholars also agreed directional link between energy and poverty reduction while some disagreed on the casual link between energy consumption and economic growth and by extension the role of energy in poverty reduction. Those that found unidirectional causality between energy consumption and economic growth include Fatai (2004), Worde-Rufai (2005) and Masih and Masih (1997). Others whose works supported bidirectional causality between energy consumption and economic growth are Morimoto and Hope (2004) and Lee and Lee (2010). Ghali and El-sakke (2004), Lee and Chien (2010) also argued that energy consumption has a natural impact on economic growth.

In 2015, USA with a population of about 324 million had 3,911,000 million kw.h/year electricity consumption, with average electrical energy per capital of 12071 and average per capita (watts per person) of 1377 watts. In 2014, France and South Africa with 66.8 $\mathrm{m}$ and $54.3 \mathrm{~m}$ as their population have electricity consumption of $431,000 \mathrm{kw}$ and $212,000 \mathrm{kw}$ respectively, also their average electrical energy per capita were $6448 \mathrm{kw}$ and $3904 \mathrm{kw}$, while average power per capita were 736 and 445 watts. Nigeria has a large estimated population of 186.1 million. Her average electrical energy per capita and average power per capita stood at $128 \mathrm{kw}$ and 14 watts respectively. From the above analysis, Nigeria performed poorly compared with France with about 36\% population of Nigerian consumed $1796 \%$ of what Nigeria consumed in 2014. Also, France had $6448 \mathrm{kw}$ average electrical per capita, 736 watt average power per capita while Nigeria had $128 \mathrm{kw}$ average electrical per capita and 14watts average power per capita.

\subsection{Electricity Situation in Nigeria}

The electricity supply in Nigeria used to be anchored by a public corporation known as National Electric Power Authority (NEPA). In
1999, under the military regime of General AbusalamAbubakar, he initiated the privatization of public enterprises which later changed the name to Power Holding Company of Nigeria (PHCN). During this time, Electricity supply is on exclusive list of the Federal Government under the control of PHCN and some operators that augment the generation and distribution of electricity to all parts of the country.

On 30 September 2013, following the privatization process initiated by the Goodluck Jonathan regime, PHCN ceased to exist. In its stead, the Nigerian Electricity Regulatory Commission (NERC) was formed. Consequently, electricity generation, transmission and distribution were anchored by different bodies namely Generating Companies of Nigeria (GENCOs), Transmission Company of Nigeria (TRN) and Distribution Company of Nigeria (DISCOs) respectively. Generating companies rely on thermal and hydropower to generate electricity. Also, electricity is a consumer of fuel and energy-fuel oil, natural gas and diesel oil. At present, the entire generated electricity in the country is pooled in the national grid at the national control center, Oshogbo from where electricity is distributed nationwide.

The reforms in the power sector which resulted in the change of NEPA (Nigeria Electricity Power Authority) to PHCN (Power Holding Company of Nigeria) in 2005 with its breaking down into 18 successive companies, comprising six generating, one transmission and eleven distribution companies. The outfits were to be selfsustaining, profit oriented and customer-driven. The employees of each companies / organizations are empowered to function with greater financial and administrative autonomy as well as be more responsive and accountable for efficient performance. The reforms also paved way for the establishment of the Nigerian Electricity Regulating Commission (NERC) and Rural Electrification Agency. The regulatory commission has supervisory and monitoring responsibility over the sector. The role of the rural electrification agency is to ensure that more than $50 \%$ of the population that live in the rural areas will have access to electricity.

\section{LITERATURE REVIEW AND CONCEPTUAL ISSUES}

\subsection{Concept of Poverty}

Even though many people particularly the poor know that what poverty is as a result of their day experience, there appears to be no 
unanimously accepted definition of poverty. In this respect, poverty has been conceptualized from different perspectives economically, socially, politically or anthropologically. Poverty has often been defined as a situation of low income or low consumption. This has often been used for constructing the poverty line which is a measure that separates the poor from the non-poor. The poor are those who are unable to obtain an adequate income, find a stable job, own property or maintain basic healthy living conditions. They also lack an adequate level of education. Thus the poor are often illiterate, in poor health and have a short life span (World Bank, 1995). They have no access to the basic necessities of life such as food, clothing and decent shelter. These class of people in the society are unable to meet social and economic obligations, they lack skills and gainful employment, if any economic assets and sometimes, lacks of self-esteem (Obadan, 2002). The current international practice puts the poverty line at US $\$ 1.0$ or sometimes US $\$ 2.0$ per day depending on the particular degree of poverty being portrayed.

Rural poverty has tended to result from the exploitation of the rural population by the urban elites and middlemen and women and the concomitant neglect by the nation's economic planners. The underlying factors of poverty are deep and complex and relate is economic social, technological and political factors of crucial dimensions, a sustainable electricity supply. Supply approach to poverty reduction becomes appealing. Stainable electricity supply will aid the artisans, traders, farmers with storage facilities, reduce the rural-urban immigration, improve the standard of living in the rural areas, and encourage rural industrialization and capital formation. This will all have positive effects on the economic growth of the country. Most rural communities are not connected to the natural gird system and therefore lack the electricity based infrastructures that would empower the establishment of social, economic and industrial amenities.

According to Oyedepo (2012), about $60 \%$ to $70 \%$ of Nigerian does not have access to electricity and it is fundamental for socio economic development and poverty eradication, According to him, the energy crisis that engulfed Nigeria for more than two decades has contributed to the incidence of poverty by paralyzing the industrial and commercial activities which have cumulated into high poverty rates.

Ogunjobi (2015) studies the relationship between electricity consumption and industrial growth in Nigeria using co-integration, the study established that in long-run, there is a significant positive relationship between electricity consumption and industrial growth and labour employment. The study therefore recommends that government should undertake prompt measure to increase electricity supply in order to increase industrial production and to reduce high rate of unemployment in Nigeria.

Girma et al. (2015) study the impact of rural electrification on poverty reduction in Northern Ethiopia. The study was premised upon and objective to determine the impact of rural electrification programme on household's income, health and education and on farming activities. Primary data was used while legit regression was also used to estimate the impact of electrification on poverty. The result shows that the impact of electricity on reduction of poverty is positive and significant while the impact of electricity access on household income is found to be positive but insignificant.

Audu et al. (2017) in their research titled "privatization of power sector and poverty of power supply in Nigeria: A policy analysis." The objective of the study is to assess the challenges facing the power sector reform programme in Nigeria. Secondary data was sourced and "Elite Theory" was adopted to discover Elite conspiracy and sabotage in power problem. The study reveals that privatization of the electricity industry in Nigeria was faced with challenges of corruption in the bidding process by the nation's ruling elite. The study advised government to amend the enabling Power Sector Reformer Act 2005 to prevent manipulation and corruption in subsequent bidding process.

In their contribution to impact of energy consumption on poverty reduction, Okwanya and Abah (2018) investigate the impact of energy consumption in poverty reduction in 12 African countries over a period of 34 years. The study adopt fully modified OLS method, the study revealed a long-run negative relationship between energy consumption and poverty level. The study also revealed that other variables such as capital stock and political stability have significant effect on poverty. The findings suggested that increasing energy consumption leads to a decline in poverty level. They further advised governments in the selected countries to improve energy infrastructure to maximize the impact of energy consumption of poverty reduction.

Estache et al. (2002) examined the relationship between infrastructure reforms and poverty alleviation in Latin American. In their analysis, both the micro and macroeconomics linkages between infrastructure reforms poverty reduction were examined. Their findings shows that one percent $(1 \%)$ increase in infrastructural stock per capital, while holding human capital constant is associated with 0.35 percent reduction in poverty ratio. The study suggests that infrastructure investment has a role to play in poverty reduction; physical infrastructure has to be substantial so as to promote rapid reduction in poverty.

From the study conducted by Oguzor (2011), it revealed that the distribution of infrastructural facilities between rural and urban areas and escalation of poverty in urban areas. His finding shows that the distribution of infrastructural facilities exhibit urban bias in Nigeria, causing increased in urban center and the neglect of agriculture. Alex and Ologuagba (2011) examined the relationship between infrastructure development and poverty reduction. They found out that the provision of basic infrastructure is a pre-requisite for economic recovery and poverty reduction and panacea for increased agricultural productivity.

\subsection{Theoretical Framework}

This study is based on the Romer model of endogenous variable. Romer (1986) established the endogenous growth model to turn knowledge into economic and technical integrity within the system to economic growth as endogenous variable. Romer proposed four elements of growth theory, namely. 
- Neo-classical economics in the capital and labour (unskilled)

- The addition of human capital (As measured by the number of years of education.)

- The new ideas (Using patents to measure, emphasizing innovation)

- The new growth theory by Romer (1986) and Lucas (1988) which was also to explain some of the possible ways to use technology to explain the endogenous economic growth.

In neo-classical growth model, the long-run rate of growth is exogenously determined by either assuming a saving rate (the Harrod-Domer) or a rate of technical progress (Solow model).

However, the saving rate and rate of technical progress remain unexplained. Endogenous growth theory tries to overcome this shortcoming by building macroeconomic models out of microeconomics foundation. Households are assumed to maximize utility subject to budget constraints while firms maximize profit subject to production cost constraints. Due importance was given to the production of new technologies and human capital. Technology is seen as an endogenous factor which could be related to energy. Most technology is given per time is dependent on the availability of useful energy to power it. The technology here is referred to plants, machinery and other like without adequate energy supply (electricity), then these technology are practically useless and no production process can take place because no production driven without energy conversion.Energy is not the sole determinant of technology but is a necessary factor to ensure that technology is being utilized.

Taking a clue from the technology oriented nature energy production; it is also known that energy production is capital intensive.Huge machineries are required to produce useable energy. This will mean that huge amount of capital will be required to produce energy. Therefore, huge investments must then be made on energy, not only to produce but to attain energy efficiency.

\section{MODEL SPECIFICATION}

The model specification used in this study followed the model of Romer, 1986, which emerged due to the limitations of Solow growth model.

The production function under the Solow growth model implies that $\mathrm{Y}=\mathrm{F}(\mathrm{K}, \mathrm{L})$ where technology is exogenously determined. But for the case of Romer, technology is seen as energy and is an endogenous variable.

Endogenous growth theory holds that economic growth is primarily the result of endogenous and not external forces. It also holds that investment in human capital; innovation and knowledge are significant contributors to economic growth. It also holds that policy measures can have an impact on the long-run growth rate of an economy. The aggregate production function of the endogenous theory is as $\mathrm{Y}=\mathrm{f}(\mathrm{A}, \mathrm{K}, \mathrm{L})$. Where $\mathrm{Y}$ is aggregate real output, $\mathrm{K}$ stock of capital, $\mathrm{L}$ is the stock of labour and $\mathrm{A}$ is the technology. Adopting this model, we incorporate unemployment rates while the poverty rate stands as the explained variable for the study. Therefore GNI per capital is used to measure the poverty rate being a function of labour employed, unemployment rates, energy disaggregated into electricity generation and consumption.

- Poverty - Poverty Rate (proxy by GNI PC)

- ElectricConp-Electricity Consumption

- Inflation - Inflation Rate

- ElectricGen - Electricity Generation

- Dependency - Dependency Ratio

- Unemployment - Unemployment Rate.

The functionaland parametric relationshipsamong variables for the model in this study are specified in equation (1) and (2) respectively below:

Povertyt $=\mathrm{f}($ ElectricConpt, Inflationt, ElectricGent, Dependencyt, Unemploymentt)

Povertyt $=\psi 1$ ElectricConpt $+\psi 2$ Inflationt $+\psi 3$ ElectricGent + $\psi 4$ Dependencyt $+\psi 5$ Unemploymentt $)+\varepsilon t$

Povertyt $=\gamma 1$ ElectricConpt $+\gamma 2$ Inflationt $+\gamma 3$ ElectricGent $+\gamma 4$ Dependencyt $+\gamma 5$ Unemploymentt $)+\gamma 6$ Povertyt $-1+\gamma 7$ Electric

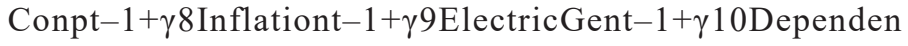

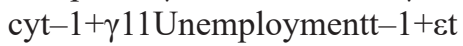

\section{UNIT ROOT TESTS}

Table 3 presents the Augmented Dickey-Fuller test in Dickey and Fuller, (1979) unit root tests. It was carried out on all the variablesto ensure that the series are not integrated of order two or higher. The results of unit root tests are reported in Table 2 and indicates that all the variables are stationary at first difference I(1) but none of them is at $\mathrm{I}(0), \mathrm{I}(2)$ or higher order of integration. This outcome satisfies the condition for the application of ARDL approach of cointegration to analyze the long-run impact of sustainable electricity supply on poverty reduction in Nigeria. Having found that the variables are not cointegrated as seen in Table 4, we therefore estimated the first difference autoregressive distributed lag (ARDL) model for the analysis in Table 5.

We have established both the internal and external validity of the model of analysis for this study going by the statistical and econometrics properties of the model. The F-statistics and R2 show that the model is of good fit and as well has a strong predictive strength. The above result can be summarized concerning the linkages between electricity consumption and poverty reduction in Nigeria. The findings, thus, can be summarized as follows.

Firstly, we have established that the effect of unemployment on poverty rate is negative and statistically significant. This reveals that lower unemployment rate does not really translate into reduction in the poverty level in Nigeria. It may seem to have contravene the theoretically expected relationship between the two variable, however one must bear in mind that most employment in the developing countries particularly in Nigeria are simply underemployment. In this case, the fact that someone is employed does not automatically imply that such job will lift the individual out of poverty. In fact majority of employment in Nigeria are found in the informal sector absence attractive pay package along with poor working condition. The few 
Table 2: The national electricity grid consist of 27 generating stations as stated below

\begin{tabular}{|c|c|c|c|c|}
\hline Plant & Community & Type & Capacity (mv) & Year of establishment \\
\hline AES Barge & Egbon & Gas Turbine & 270 & 2001 \\
\hline Aba power station & Aba & Gas Turbine & 140 & 2012 \\
\hline \multirow[t]{2}{*}{ Afan iv-v power station } & Afan & Gas Turbine & 726 & 1982 \\
\hline & & & 138 & 2002 \\
\hline Afan vi & Afan & Cycle/Gas Turbine & 624 & $2009 / 2010$ \\
\hline Alaoji power station & Abia & Cycle/Gas Turbine & 1074 & 2012-2015 \\
\hline Calabar power station & Calabar & Cycle/Gas Turbine & 561 & 2014 \\
\hline Egbema power station & Imo state & Cycle/Gas Turbine & 338 & $2012-2013$ \\
\hline Egbin thermal power station & Egbin & Gas fred steam turbine & 1320 & $1985 / 1986$ \\
\hline Geregu I power station & Kogi & Gas turbine & 414 & 2007 \\
\hline Geregu II power station & Kogi & Gas turbine & 434 & 2012 \\
\hline Ibom Power Station & IkotAbasi & Gas turbine & 190 & 2009 \\
\hline Ihovbor Power Station & Benin & Gas turbine & 450 & $2012 / 2013$ \\
\hline Okpai Power Station & Okpai & Gas turbine & 480 & 2005 \\
\hline Olorunsogo Power Station & Olorunsogo & Gas turbine & 336 & 2007 \\
\hline Olorunsogo II Power Station & Olorunsogo & Gas turbine & 675 & 2012 \\
\hline Omoku Power Station & Omoku & Gas turbine & 150 & 2005 \\
\hline Omoku II Power Station & Omoku & Gas turbine & 255 & Incomplete \\
\hline Omotosho I Power Station & Omotosho & Gas turbine & 336 & 2005 \\
\hline Omotosho II Power Station & Omotosho & Gas turbine & 450 & 2015 \\
\hline Sapele I Power Station & Sapele & Gas turbine & 1020 & 1978 \\
\hline Sapele II Power Station & Sapele & Gas turbine & 450 & 2012 \\
\hline TranscorpUghelli Power Station & Ughelli & Gas turbine & 900 & 1966-1998 \\
\hline Azura Power Station & Benin & Gas turbine & 450 & 2018 \\
\hline Itobe Power Plant & ItobeKogi & Circulating Fluidized Bed Technology & 1200 & 2018 \\
\hline Kanji Power Station & Kanji & Reservoir & 800 & 1968 \\
\hline Jebba Power Station & Jebba & Reservoir & 540 & 1985 \\
\hline Shiroro Power Station & Shiroro & Reservoir & 600 & 1990 \\
\hline Zamfara Power Station & Zamfara & Reservoir & 100 & 2012 \\
\hline
\end{tabular}

Table 3: Result of unit root test

\begin{tabular}{lllll} 
Variable & $\begin{array}{l}\text { ADF } \\
\text { (t-Statistics) }\end{array}$ & $\begin{array}{l}\text { 1 Percent } \\
\text { Critical } \\
\text { Values }\end{array}$ & $\begin{array}{l}\text { Order of } \\
\text { Integration }\end{array}$ & Remarks \\
Povertyt & -2.589388 & -2.639210 & $\mathrm{I}(1)$ & Stationary \\
ElectricConpt & -6.681144 & -3.661661 & $\mathrm{I}(1)$ & Stationary \\
Inflationt & -5.598029 & -2.632688 & $\mathrm{I}(1)$ & Stationary \\
ElectricGent & -6.776124 & -3.661661 & $\mathrm{I}(1)$ & Stationary \\
Dependency_ & -6.301751 & -3.724070 & $\mathrm{I}(1)$ & Stationary \\
Ratiot & & & & \\
Unemploymentt & -7.699923 & -2.630762 & $\mathrm{I}(1)$ & Stationary \\
\hline
\end{tabular}

Source: Authors' Computation, 2020

that are engaged in the formal sector most times underpaid and forced to work for longer hour. This is in addition to non-application of labour laws and nonexistence of institutionally established framework for job security. This confirms the results showed by Egunjobi (2014) that unemployment has a positive influence on poverty while government investment on infrastructures and that there is no causal link between poverty and unemployment.

Secondly, the poverty level in the past period is found to have a direct and statistically significant effect on the poverty rate in the current period. It does corroborate the general believe that in the underdeveloped countries, the poor are getting poorer while the rich are getting richer. In most underdeveloped nations, apparently nonexistence or at best weak economic transformation agenda backed up by strong political will aimed at lifting the poor out of poverty. This is consistent with the findings of Bello and Roslan (2010), which discovered that economic growth and MDG spending has not substantially reduced poverty over the sample period. Hence the level of poverty in the country tends to be increasing despite the fact that the country usually record positive growth in GDP.

Thirdly, electricity consumption has a statistically significant effect on poverty rate but with direct relationship. This indicates that an increase in energy consumption tends to induce poverty rate of the country contrary to a priori theoretical expectation. Since energy is considered to be an important driver of economic growth, hence, one would expect that increase in electricity consumption will demystify the scourge of poverty rate in the country. However, there appear to be fallout among few parameters that juxtapose the two variables. Apparently, the stability of electricity supply in Nigeria can best be described as abysmal, this has negatively affected the economic usage of diminutive generated into productive use that could guarantee economic boost. This accounts for the reason why the rate of electricity consumption in the country has not been able to reduce the poverty level.

Fourth, the results show that there is significant and negative impact of electricity generation on poverty level. We can therefore infer that that electricity generation reduces poverty level in the country. A high volume of electricity generation is a viable boost of productive economic activities which guarantee poverty reduction. This result is consistent with the finding of Okwanya and Abah (2010) and Hussenin and Filho (2012). From the findings of Okwanya and Abah (2010), they assert that there exists a short-run unidirectional causality runs from energy consumption to poverty. Besides this, there findings also suggest that increasing energy consumption leads to a decline in poverty level. The works of Hussenin and Filho (2012) asserts 
Table 4: Result of co-integration test

\begin{tabular}{lccc}
\multicolumn{2}{l}{ Unrestricted Cointegration Rank Test (Trace) } & & \\
\hline Hypothesized & & Trace & $\mathbf{0 . 0 5}$ \\
\hline No. of CE (s) & Eigenvalue & Statistic & Critical Value \\
None * & 0.876249 & 137.0645 & 95.75366 \\
At most 1 & 0.791585 & 86.91695 & 69.81889 \\
At most 2* & 0.686344 & 49.27962 & 47.85613 \\
At most 3 & 0.486021 & 21.45261 & 29.79707 \\
At most 4 & 0.187387 & 5.478863 & 15.49471 \\
At most 5 & 0.020571 & 0.498859 & 3.841466 \\
\hline
\end{tabular}

Trace test indicates 3 cointegrating eqn (s) at the 0.05 level

*Denotes rejection of the hypothesis at the 0.05 level

**MacKinnon-Haug-Michelis (1999) $P$ values

\begin{tabular}{|c|c|c|c|c|}
\hline \multicolumn{5}{|c|}{ Unrestricted Cointegration Rank Test (Maximum Eigenvalue) } \\
\hline Hypothesized & & Max-Eigen & 0.05 & \\
\hline No. of CE (s) & Eigenvalue & Statistic & Critical Value & Prob.** \\
\hline None * & 0.876249 & 50.14753 & 40.07757 & 0.0027 \\
\hline At most $1 *$ & 0.791585 & 37.63733 & 33.87687 & 0.0169 \\
\hline At most $2 *$ & 0.686344 & 27.82701 & 27.58434 & 0.0466 \\
\hline At most 3 & 0.486021 & 15.97375 & 21.13162 & 0.2264 \\
\hline At most 4 & 0.187387 & 4.980004 & 14.26460 & 0.7444 \\
\hline At most 5 & 0.020571 & 0.498859 & 3.841466 & 0.4800 \\
\hline
\end{tabular}

Max-eigenvalue test indicates 3 cointegrating eqn (s) at the 0.05 level

*Denotes rejection of the hypothesis at the 0.05 level

**MacKinnon-Haug-Michelis (1999) $P$ values

Source: Authors' Computation, 2020

Table 5: Result of auto-regressive distributed lag analysis

\begin{tabular}{lclcc} 
Dependent Variable: Poverty Rate & & & & \\
Variable & Coefficient & Std. Error & t-Statistic & Prob. \\
Dependency_Ratiot & 0.009547 & 0.010641 & 0.897220 & 0.3859 \\
ElectricConpt & -0.001003 & 0.003013 & -0.332943 & 0.696218 \\
ElectricGent & 0.001511 & 0.002170 & -0.962888 & 0.4986 \\
Inflationt & -0.000205 & 0.000213 & -2.153724 & 0.3532 \\
Unemploymentt* & -0.013336 & 0.006192 & 2.890097 & 0.0506 \\
Povertyt-1** & 0.596251 & 0.206308 & -0.666067 & 0.0126 \\
Dependency_Ratiot-1 & -0.007034 & 0.010561 & 3.476875 & 0.5170 \\
ElectricConpt-1*** & 0.008615 & 0.002478 & -3.336776 & 0.0041 \\
ElectricGent-1*** & -0.006563 & 0.001967 & -0.817789 & 0.0054 \\
Inflationt-1 & -0.000152 & 0.000186 & 1.076928 & 0.4282 \\
Unemploymentt-1 & 0.013540 & 0.012573 & -0.559131 & 0.3011 \\
C & -0.142477 & 0.254819 & & 0.5856 \\
R-squared & 0.980342 & Mean dependent variable & & 0.213360 \\
Adjusted R-squared & 0.963708 & S.D. dependent variable & & 0.058675 \\
S.E. of regression & 0.011178 & Akaike info criterion & & -5.843699 \\
Sum squared residual & 0.001624 & Schwarz criterion & & -5.258638 \\
Log likelihood & 85.04623 & Hannan-Quinn criterion & & -5.681428 \\
F-statistic & 58.93684 & Durbin-Watson stat & & \\
Probability (F-statistic) & & & 0.000000 & \\
\hline
\end{tabular}

Source: Authors' Computation, 2020

that energy can have major favorable effects in remote rural areas and renewable energy technologies offer a key prospect in areas where the grid cannot reach. Reliance of the poor on their natural surroundings indicates that any step towards poverty alleviation should incorporate environmental and economic sustainability as a priority for sustainable livelihoods.

\section{CONCLUSION}

The attention of most policy makers among Africa countries are been drawn to ever increasing spate of poverty in the continent. Nigeria in particular has been declared are as a country with the second largest population of the people living in poverty globally after India. Although, several policy measures are meant to be put in place in a way to reducing poverty, however, most African countries are faced with problems such as poor infrastructural facilities, political instability, income inequality and other macroeconomic instabilities that tend to inhibit the efficacy of energy-GDP relationship on poverty level. This study aimed at understanding how increase in energy supply with the hope of meeting the energy needs and ensuring poverty reduction. This study will make immense contribution to literature. It investigates the nexus between electricity consumption, electricity generation, inflation rate, dependency ratio, unemployment, and poverty level in Nigeria over 38-year period. 
On the basis of the long-run relationship between electricity generation, electricity consumption, unemployment and poverty level, we can suggest that although electricity plays an important role on economic growth, its role in reducing poverty rate is secondary. Bearing in mind that electricity generation is one issue worthy of note, also electricity consumption is another area that one must treat separately. Thus, the hypothesis of increasing electricity supply so as to reduce poverty should be carefully studied in Nigeria.

There is an important difference between the urban and rural poor with respect to access to electricity infrastructure. Most of the time for the urban poor the electricity services are there for them to access, whereas for the rural poor the services are not there in the first place. Based on the outcome of this study, it could be seen clearly that while electricity generation play a significantly role reducing poverty in the country, electricity consumption does not guarantee poverty reduction. It is now popularly acknowledge that energy sector reforms translates into long term benefits for the populace most especially in poverty reduction and economic growth. This is achievable through economic innovation, efficiency in production and service delivery. Apart from that, a boosts in private investment, provision of enabling business environment for micro and small scale enterprises (MSMEs), reduced burden on public sector finances, better targeting of subsidies and increased investments will be achieved if adequate electricity can be generated.

The revelation that poverty level in the past period is found to have a direct and statistically significant effect on the poverty rate in the current period, is a pointer that most poverty reduction strategies should be geared towards the need to increase income levels of the poor through improved access to income earning opportunities and to improve quality of life through better access to basic social services such as health, education and clean water and sanitation. Governments of Nigeria, donors and other stakeholders nevertheless must recognizeelectricity generation as the essential ingredient for making the poverty reduction strategies more effective. Thus electricity generation should be given more attention.

While addressing the problem of poverty from employment angle, we must also bear in mind the outcome of this study that lower unemployment rate does not really translate into reduction in the poverty level in Nigeria. Hence, in trying to address the menace of unemployment in the country, underemployment and labour exploitation must also be tackled headlong.

\section{ACKNOWLEDGMENTS}

The authors wish to appreciate the management of Landmark University for making provisions to sponsor the open access fee of this article.

\section{REFERENCES}

Adegbulugbe, A., Akinbami, J. (2002), Policy options for the attainment of sustainable electricity supply in Nigeria. CBN Billion, 26(4), 3-12. Alamu, S.O., Abiodun, J.A(2006), Food Security and Poverty Alleviation.
Ilorin: 19th Annual Conference of the Fisheries Society of Nigeria.

Audu, E., Paul, S.O., Ameh, E. (2017), Privatization of power sector and poverty of power supply in Nigeria; a policy analysis. International Journal of Development and Sustainability, 6(10), 1218-1231.

Bello, M.A., Roslan, A.H. (2010), Has poverty reduced in Nigeria 20 years after? European Journal of Social Sciences, 15(1), 23-34.

Breshin, S. (2004), The Power Sector and its Impact Indusrtialization Buisness in Nigeria.

Egunjobi, T.A. (2014), Poverty and unemployment paradox in Nigeria. IOSR Journal of Humanities and Social Science, 19(5), 106-116.

Fatai, K. (2004), Modeling the casual relationship between consumption and GDP in New Zealand. Mathematics and Computer in Simulations, 64(3), 431-445.

Ghali, K.H., El-Sakka, M.I.T. (2004), Energy use and output growth in Canada. Energy Economics, 26(2), 222-238.

Girma, T., Girma, B., Dereje, T. (2015), Impact of rural electrification on poverty reduction, evidence from rural district of Tigrai, Norhern Ethiopia. Journal of Business Management and Social Sciences Research, 4(1), 1-10.

Hussenin, M.A., Filho, W.L. (2012), Analysis of energy as a precondition for improvement of living conditions and poverty reduction in subSaharan Africa. Scientific Research and Essays, 7(30), 2656-2666.

Lee, C.C. (2010), Dynamic modeling of energy consumption, capital stock and real income in G.F countries. Energy Economic, 32(3), 564-581.

Lee, J.H., Lee, J. (2010), Indole as an intercellular signal in microbial. FEMS Microbial Review, 34(4), 426-444.

Makoju. (2013), The Power Sector: An Operator's Perspective: The Presidential Legacy: 1999-2007. Ibadan Book Craft.

Masih, A., Masih, R. (1997), Causal relationship between energy, real income and prices. Journal of Policy Modeling, 19(4), 417-440.

Morimoto, R., Hope, C. (2004), Household electricity consumption of middle class family in Chittagong. Energy Economics, 26, 77-85.

Obadan, M.I. (2002), Poverty reduction in Nigeria: The way forward. CBN Economic and Financial Review, 39(4), 1-10.

Ogunjobi, J.O. (2015), The effect of electricity consumption on industrial growth in Nigeria. Journal of Sustenance and Development, 6(13), 20-30.

Ogunjobi, O., Eseyin, O., Popoola, O. (2021), Human capital and energy infrastructure: Implications for economic growth in Nigeria. International Journal of Energy Economics and Policy, 11(3), 1-6. Available from: http://www.econjournals.com/index.php/ijeep/ article/view/10066

Oguzor, N.S. (2011), A spartial analysis of infrastructures and social services in rural Nigeria: Implication for public policy. Journal of GeoTropico, 5(1), 25-38.

Okwanya, I., Abah, P.O. (2018), Impact of energy consumption on poverty reduction in Africa. CBN Journal of Applied Statistics, 9(1), 105-139.

Oyedepo, S.O. (2012), Energy and sustainable development in Nigeria. The way forward, energy. Sustainability and Society, 2(15), 20-31.

Romer, P.M. (1986), Increasing returns and long-run growth. The Journal of Political Economy, 94(5), 1002-1037.

Sanchis. (2007), Quantifying the Contribution of Electricity to Spanish Economic Growth during the Twentieth Century. Valencia: Paper Presented at III Barometric. p23-24.

Ulsrud, K., Winther, I., Palit, D., Rohracher, H. (2018), Pathways to electricity for all. What makes village scale solar power successfully? Energy Research and Social Sciences, 44, 32-40.

Worde-Rufai, Y. (2005), Energy demand and economic growth: The African experience. Journal of Policy Modeling, 27(8), 891-903.

World Bank. (1996), The World Bank Annual Report (English). Washington, DC. World Bank.

World Bank. (2017), The World Bank Annual Report, Washington, DC: World Bank. 